\title{
Composition, antioxidant properties, and biological activities of the essential oil extracted from Ocotea diospyrifolia (Meisn.) Mez.
}

\author{
Natasha Tiemi Fabri®1*, Larissa Junqueira Gatto', Alethéia Santos Furusho', \\ Meira Janette Ballestros Garcia' ${ }^{2}$, Francisco de Assis Marques², Marilis Dallarmi Miguel', \\ Deise Prehs Montrucchio ${ }^{1}$, Sandra Maria Warumby Zanin ${ }^{1}$, Obdulio Gomes Miguel ${ }^{\circledR 1}$, \\ Josiane de Fátima Gaspari Dias ${ }^{1}$
}

\begin{abstract}
${ }^{1}$ Laboratory of Natural Products, Pharmacy Department, Federal University of Paraná, Curitiba, Brazil, ${ }^{2}$ Laboratory of Chemical Ecology and Synthesis of Natural Products, Chemistry Department, Federal University of Paraná, Curitiba, Brazil
\end{abstract}

\begin{abstract}
The article has aimed to characterize the essential oil extracted from Ocotea diospyrifolia (Meisn.) Mez. leaves, in terms of its chemical composition and antioxidant, hemolytic, and phytotoxic potentials, as well as its toxicity against Artemia salina. The major constituents identified by CG-MS were $\delta$-elemene, spathulenol, and $\beta$-atlantol. When screened for potential biological activities, the essential oil presented low toxicity against Artemia salina, and a capacity of lysing red blood cells. Also, the evaluation of its in vitro antioxidant activity, using the phosphomolybdenum method, showed better results when compared to butylhydroxytoluene (BHT) and rutin. In conclusion, the results obtained showed certain in vitro toxicity, leading to an interesting target for cytotoxicity evaluations of carcinoma cells.
\end{abstract}

Keywords: Ocotea diospyrifolia. Lauraceae. Spathulenol. Antioxidant. Toxicity.

\section{INTRODUCTION}

The essential oils extracted from the Ocotea genus have demonstrated potential in the biological and pharmacological activities field. Studies have shown positive results regarding antioxidant, antimicrobial (Bruni et al., 2004; Cansian et al., 2010; Salleh, Ahmad, 2017), cytotoxic, anti-inflammatory, cardiovascular, molluscicidal, and anti-malarial activities (Salleh, Ahmad, 2017) as well as toxicity against Artemia salina (Damasceno et al., 2018).

Ocotea diospyrifolia (Meisn.) Mez., a species belonging to this genus and Lauraceae family, is commonly found in Argentina, Paraguay, and Brazil (Marques, 2001). It has a commercial value for the timber industry (Ruschel et al., 2003), and is commonly used for construction (Marques, 2001), similar to the other Ocotea species (Duke, Vásquez, 1994). Based on this information, it can be assumed that when processed by the

\footnotetext{
*Correspondence: N. T. Fabri. Departamento de Farmácia, Universidade Federal do Paraná. Rua Prefeito Lothário Meissner 632, Curitiba, Paraná, Brazil. Phone: +55 4198505 8166. E-mail: natasha.fabri@gmail.com
}

industry, the leaves of the Ocotea diospyrifolia might go to waste. Regarding its activities, the larvicide effect of the leaves and stems against ticks has already been reported (Santos et al., 2013); as well as the antimicrobial activity of the leaves (Weber et al., 2018).

Thus, this article's objective consisted in characterizing the chemical composition of the essential oil, extracted from Ocotea diospyrifolia (Meisn.) Mez. leaves, and evaluate its antioxidant, hemolytic, and phytotoxic potential, as well as its toxicity against Artemia salina. To our knowledge, this is the first study concerning the essential oil of the Ocotea diospyrifolia.

\section{MATERIAL AND METHODS}

\section{Plant material}

Leaves of the Ocotea diospyrifolia (Meisn.) Mez. were collected in Curitiba, Brazil (25 26' S, 49 $14^{\circ}$ ' W), during winter (July). A voucher specimen was deposited in the herbarium, from the Municipal Botanical Museum of Curitiba, under the registration number MBM 385265. The material collected was dried at room temperature, ground, and carried away for oil extraction. 


\section{Essential oil extraction and characterization}

The essential oil was extracted via hydrodistillation, using a Clevenger apparatus, based on the technique described in the Farmacopeia Brasileira (2010). The process lasted six hours, and it was performed with $600 \mathrm{~g}$ of dried and ground leaves, and 3.5L of distilled water.

\section{Determination of the volatile composition}

The oil was further submitted to a GC-MS analysis in a Shimadzu CGMS QP2010 Plus equipment, using the RTX-5MS fused capillary column $(30 \mathrm{~m} \times 0.25 \mathrm{~mm}$ $\mathrm{x} 0.25 \mu \mathrm{m}$ film thickness), with helium $(1.0 \mathrm{~mL} / \mathrm{min})$ as the carrier gas. The split flow was adjusted to provide a 20:1 ratio. The injector and detector temperatures were adjusted to $250{ }^{\circ} \mathrm{C}$. The programmed oven temperature was $60-280^{\circ} \mathrm{C}$ at $5^{\circ} \mathrm{C} / \mathrm{min}$.; the electron impact mass spectrometry (EIMS): electron energy was $70 \mathrm{eV}$; the ion source temperature and the connection parts were at adjusted at $180{ }^{\circ} \mathrm{C}$. Individual components were identified by comparing their arithmetic indices (AI) to a homologous series of C9-C20, and the mass spectra, with those of authentic compounds as stated in Adams' libraries of mass spectral data (Adams, 1995), and a computer data bank, using Wiley 275, NIST 21, NIST 107 (NIST 10).

\section{Antioxidant activity - 2,2-diphenyl-1-picrylhyrazyl (DPPH•) scavenging assay}

The technique used was adapted from the literature (Mensor et al., 2001). Methanolic solutions, from the sample and controls (ascorbic acid, BHT and rutin), were prepared at $200 \mu \mathrm{g} / \mathrm{mL}$. For the essential oil, it was necessary to add Tween $80 \circledR(200 \mu \mathrm{g} / \mathrm{mL})$. In a 96-well microplate, $60 \mu \mathrm{L}$ of a methanolic DPPH• solution $(0.3 \mathrm{mM})$ was added to $140 \mu \mathrm{L}$ of the sample/control. The dilution solvent was used as a negative control, and a blank was made to discount the sample's color. The mixture was protected from light for 30 minutes and read using a microplate spectrophotometer at $540 \mathrm{~nm}$.

\section{Antioxidant activity-Formation of the phosphomolybdenum complex assay}

Sample and positive controls (ascorbic acid, BHT and rutin) were prepared as described for the DDPH• scavenging assay. The antioxidant activity was measured as published previously (Prieto, Pineda, Aguilar, 1999). Three milliliters of the reagent (sulfuric acid $0.6 \mathrm{M}$, sodium phosphate $28 \mathrm{mM}$, ammonium molibdate $4 \mathrm{mM}$ ) was added to a tube, followed by $0.3 \mathrm{~mL}$ of the sample/ control. A blank was prepared with $0.3 \mathrm{~mL}$ of a dilution solvent and $3 \mathrm{~mL}$ of the reagent. The resultant solution was maintained at $95{ }^{\circ} \mathrm{C}$ in a water bath, for 90 minutes, and read in spectrophotometer at $690 \mathrm{~nm}$. The results were expressed as relative antioxidant activity (RAA\%), compared to each positive control.

\section{Antioxidant activity $-\beta$-carotene bleaching assay}

This technique was followed as previously described (Rufino et al., 2006), with some adaptations. The controls (ascorbic acid, BHT, and rutin) and essential oil were diluted to $200 \mu \mathrm{g} / \mathrm{mL}$ in methanol; for the essential oil solution, Tween $80 \AA(1: 1 \mathrm{w} / \mathrm{v})$, was added. $A \beta$-carotene/ linoleic acid system was prepared as an emulsion, mixing $40 \mu \mathrm{L}$ of linoleic acid, $530 \mathrm{mg}$ of Tween $80 \AA, 50 \mu \mathrm{L}$ of a $\beta$-carotene solution ( $20 \mathrm{mg} / \mathrm{mL}$ in chloroform), and $20 \mathrm{~mL}$ of oxygenated distilled water. The antioxidant activity was determined in a microplate, where $150 \mu \mathrm{L}$ of the emulsion was added to $20 \mu \mathrm{L}$ of the sample/controls. The blank was prepared using $20 \mu \mathrm{L}$ of methanol instead of the sample. The microplate was read in a spectrophotometer $(470 \mathrm{~nm})$, incubated at $50{ }^{\circ} \mathrm{C}$, and read again every 15 minutes for 120 minutes. The protection capacity (\%) was calculated as follows:

$$
\operatorname{Protection}(\%)=\left[1-\frac{\left(\text { Abs initial }_{\text {sample }}-\text { Abs } \text { final }_{\text {sample }}\right)}{\left(\text { Abs inicial }_{\text {blank }}-\text { Abs } \text { final }_{\text {blank }}\right)}\right] \times 100
$$

where: Abs initial ${ }_{\text {sample }}=$ sample absorbance at 0 minutes; Abs final sample $=$ sample absorbance at 120 minutes; Abs initial blank $=$ blank absorbance at 0 minutes; Abs final ${ }_{\text {blank }}=$ blank absorbance at 120 minutes.

The absorbance decay profile was evaluated at two points of the kinetic study (at 30 and 82.5 minutes), where the F1 and F2 values were calculated (DuarteAlmeida et al., 2006):

$$
F 1=\frac{\operatorname{tg} \text { sample } 30}{\operatorname{tg} \text { blank } 30} \quad F 2=\frac{\operatorname{tg} \text { sample } 82.5}{\operatorname{tg} \text { blank } 82.5}
$$

where, tg sample $30 / 82.5=$ sample tangent, when $\mathrm{x}=30 / 82.5$ minutes; tg blank $30=$ blank tangent, when $\mathrm{x}=30 / 82.5$ minutes.

\section{Lethality against brine shrimp}

The evaluation of in vitro toxicity against Artemia salina was carried out as described previously (Meyer et al., 1982). The essential oil was diluted in methanol, and 
Tween $80 \circledR$ was added to facilitate the solubilization (same concentration as the sample). Quinidine sulfate was used as a positive control. Both the sample and the control were prepared in the following concentrations: 10, 50, 100, 250, 500, 750, and $1000 \mu \mathrm{g} / \mathrm{mL}$. Eggs of Artemia salina were hatched in an artificial marine salt solution (38g/L; pH 8-9; constant aeration; 48 hours). Ten nauplii were put in contact with the sample/control solution for 24 hours, and the number of alive and dead Artemia salina were counted. The results were analyzed, using the Probit statistical method, to calculate the $\mathrm{LC}_{50}$.

\section{Hemolytic activity}

The methodology used for evaluating hemolytic activity was adapted from the literature (Banerjee et al., 2008). The essential oil was diluted to the concentrations of $100,250,500,750$ and $1000 \mu \mathrm{g} / \mathrm{mL}$ in phosphate buffered saline (PBS) of $\mathrm{pH} 7.4 ; 1 \%$ methanol (v/v), and $0.5 \%$ dimethylsulfoxide $(\mathrm{v} / \mathrm{v})$ were also added. Saponine was used as the standard and prepared in the same concentrations using $1 \%$ methanol in PBS. Three milliliters of defibrinated sheep blood was centrifuged in a falcon tube for 5 minutes $(3000 \mathrm{rpm})$. The supernatant was discarded, and the remaining tube material was washed with $5 \mathrm{ml}$ of PBS and centrifuged at $3000 \mathrm{rpm}$ for 5 minutes. The procedure was repeated thrice, or until the supernatant was clean. The resultant red blood cells were diluted to $2 \%(\mathrm{w} / \mathrm{v})$ in PBS. For the hemolytic activity measurement, $200 \mu \mathrm{L}$ of sample/standard was added to an Eppendorf, followed by the $200 \mu \mathrm{L}$ suspension of red blood cells. A blank was used to discount the sample's color (200 L sample/positive control $+200 \mu \mathrm{L} \mathrm{PBS}$ ), and the negative control was composed of $200 \mu \mathrm{L} \mathrm{RBC}+$ $200 \mu \mathrm{L}$ of solvent. All the samples and the standard were measured based on two positive controls; potable water and a triton $(10 \mu \mathrm{g} / \mathrm{mL}$ in PBS $)$. The Eppendorf tubes were incubated at $37^{\circ} \mathrm{C}$ for 3 hours and centrifuged for 5 minutes at $3000 \mathrm{rpm}$. Around $150 \mu \mathrm{L}$ of the supernatant was transferred to a microplate, which was read in a spectrophotometer at $540 \mathrm{~nm}$.

The results were expressed as a percentage of hemolysis, assuming $100 \%$ of the activity for absorbance was obtained utilizing the triton and potable water.

\section{Phytotoxic activity}

For the allelopathic activity (adapted from Silva, Overbeck, Soares, 2014), the essential oil was diluted in methanol and Tween $80 \AA(1: 1 \mathrm{w} / \mathrm{w}$ with the sample $)$ to $0.001,0.01,0.1$ and $1 \%(\mathrm{w} / \mathrm{v})$. A filter paper was inserted in a Gerbox, with $5 \mathrm{~mL}$ of distilled water and 20 Lactuca sativa cv. Grand Rapids seeds (Feltrin ${ }^{\circledR}$ ), were disposed in four quadrants. Two filter papers were placed in the lid, with $3 \mathrm{~mL}$ of the sample. Distilled water was used as a negative control, and methanol + Tween $80 \AA$ was used to guarantee that the solvent had no effect. The Gerboxes were wrapped in a plastic film and placed in an incubator $\left(20 \pm 5^{\circ} \mathrm{C}\right)$ for 7 days. For each concentration, two Gerboxes were prepared, for germination and growth evaluation. The germination samples were analyzed daily; the germinated seeds were counted and taken from the box. Growth was observed only on the seventh day, when the radicle and hypocotyl were measured using a ruler.

\section{Statistical analyses}

The results obtained, with the antioxidant and hemolytic activities, were submitted to a variance (ANOVA), and mean comparison (Tukey) analyses. The results from the phytotoxic assay were analyzed utilizing the Scott-Knot test; the lethality against Artemia salina was evaluated using the Probit method, to calculate the $\mathrm{LC}_{50}$. All the statistical analyses were conducted with a significance level of $95 \%$.

\section{RESULTS AND DISCUSSION}

The extraction of the essential oil from the leaves of Ocotea diospyrifolia (Meisn.) Mez. had a yield of $0.21 \%$ $(\mathrm{v} / \mathrm{w})$, and the chemical composition has been provided in Table I.

A total of 26 compounds were identified ( $86.53 \%$ of the sample). The essential oil was predominantly composed of sesquiterpenes $(85.7 \%)$, and mostly hydrocarbons $(55.91 \%)$. Oxygenated sesquiterpenes comprised $29.79 \%$ of the sample. A similar profile was found for the leaves of the Ocotea brenesii Standl., 54.3\% of which was composed of hydrocarbon sesquiterpenes and $29.9 \%$ of oxygenated sesquiterpenes (Chaverri, Cicció, 2005).

The three major constituents that were discovered were the $\delta$-elemene (25.93\%), spathulenol (11.4\%), and $\beta$-atlantol (15.35\%). In previous studies, the $\delta$-elemene demonstrated containing antitumor activity against cervical (Wang et al., 2006) and colorectal carcinomas (Xie et al., 2009). It is interesting to notice that its isomer, $\beta$-elemene, is also present in a considerable amount $(9.49 \%)$ and together they make up $35 \%$ of the essential oil. The $\beta$ isomer was also evaluated regarding its anticancer properties. Studies showed that the $\beta$-elemene inhibited the metastasis of mammalian carcinoma cells 
TABLE I - Composition of the essential oil of Ocotea diospyrifolia (Meisn.) Mez. leaves extracted via hydrodistillation

\begin{tabular}{|c|c|c|c|c|}
\hline AI & Literature AI & Component & {$[\%]$} & Classification \\
\hline 928 & 932 & $\alpha$-Pinene & 0.2 & Bicyclic monoterpene \\
\hline 967 & 974 & $\beta$-Pinene & 0.37 & Bicyclic monoterpene \\
\hline 1019 & 1024 & Limonene & 0.26 & Bicyclic monoterpene \\
\hline 1330 & 1335 & $\delta$-Elemene & 25.93 & Monocyclic sesquiterpene \\
\hline 1360 & 1374 & Isoledene & 1.03 & Bicyclic sesquiterpene \\
\hline 1363 & 1373 & $\alpha$-Ylangene & 0.49 & Bicyclic sesquiterpene \\
\hline 1368 & 1374 & $\alpha$-Copaene & 1.00 & Bicyclic sesquiterpene \\
\hline 1381 & 1389 & $\beta$-Elemene & 9.49 & Monocyclic sesquiterpene \\
\hline 1407 & 1408 & (Z)-Caryophylenne & 1.08 & Bicyclic sesquiterpene \\
\hline 1417 & 1430 & $\beta$-Copaene & 0.26 & Bicyclic sesquiterpene \\
\hline 1421 & 1434 & $\gamma$-Elemene & 2.86 & Monocyclic sesquiterpene \\
\hline 1427 & 1439 & Aromadendrene & 0.54 & Tricyclic sesquiterpene \\
\hline 1440 & 1452 & $\alpha$-Humulene & 0.92 & Monocyclic sesquiterpene \\
\hline 1463 & 1458 & allo-Aromadendrene & 1.92 & Tricyclic sesquiterpene \\
\hline 1466 & 1478 & $\gamma$-Muurolene & 1.70 & Bicyclic sesquiterpene \\
\hline 1471 & - & NI & 0.53 & - \\
\hline 1482 & 1500 & Bicyclogermacrene & 2.19 & Bicyclic sesquiterpene \\
\hline 1486 & 1500 & $\alpha$-Muurolene & 1.26 & Bicyclic sesquiterpene \\
\hline 1497 & 1495 & $\gamma$-amorphene & 0.39 & Bicyclic sesquiterpene \\
\hline 1508 & 1511 & $\delta$-Amorphene & 0.49 & Bicyclic sesquiterpene \\
\hline 1526 & 1546 & Elemol & 0.54 & Monocyclic sesquiterpene alcohol \\
\hline 1540 & 1559 & Germacrene B & 4.36 & Monocyclic sesquiterpene \\
\hline 1553 & 1577 & Spathulenol & 11.4 & Bicyclic sesquiterpene alcohol \\
\hline 1564 & - & NI & 0.67 & - \\
\hline 1569 & - & NI & 0.75 & - \\
\hline 1573 & - & NI & 0.99 & - \\
\hline 1596 & - & NI & 0.49 & - \\
\hline 1602 & 1608 & $\beta$-Atlantol & 15.35 & Monocyclic sesquiterpene alcohol \\
\hline 1611 & - & NI & 1.00 & - \\
\hline 1620 & - & NI & 0.72 & - \\
\hline 1626 & 1639 & allo-Aromadendrene epoxide & 0.84 & Oxygenated tetracyclic sesquiterpene \\
\hline 1631 & - & NI & 0.59 & - \\
\hline 1635 & 1668 & trans-Calamenen-10-ol & 0.54 & Bicyclic sesquiterpene alcohol \\
\hline 1677 & 1668 & 14-hydroxy-9-epi-(E)-Caryophyllene & 1.12 & Bicyclic sesquiterpene alcohol \\
\hline 1753 & - & NI & 1.55 & - \\
\hline 1807 & - & NI & 0.43 & - \\
\hline Total & & & 92.45 & - \\
\hline
\end{tabular}

AI: Arithmetical index; NI: Not identified 
in vitro (Zhang et al., 2013), and had a synergistic effect along with etoposide against lung carcinoma (Zhang et al., 2011).

Spathulenol, the second major substance, was seen to be capable in increasing the susceptibility of multiresistant lymphoma to chemotherapies, by inhibiting the efflux pump of cells (Martins et al., 2010).

When compared to other plants from the Ocotea genus, the essential oil from the leaves of Ocotea diospyrifolia exhibited a different composition. According to the literature, from the ten Ocotea species evaluated $(O$. floribunda, O. holdrigdeana, O. meziana, O. sinuata, $O$. tonduzii, O. valeriana, O. veraguensis, $O$. whitei, Ocotea new species "los llanos", Ocotea new species "small leaf"), nine substances were found to be commonly present in the essential oils (Takaku, Haber, Setzer, 2007). Among these compounds, only four of them were found in the oil analyzed in this study: $\alpha$ and $\beta$-pinene, $\beta$-elemene, and $\alpha$-humuleno.

Regarding the antioxidant activity, the results from the DPPH• scavenging and the phosphomolybdenum complex formation assay have been summarized in Table II.

In the DPPH• scavenging assay, the essential oil inhibition capacity $(10.22 \%)$ was far below the values found for ascorbic acid, BHT, and rutin. On the other hand, the phosphomolybdenum complex formation demonstrated better antioxidant activity for the oil, when compared to BHT and rutin. The variance in these results might be explained by the differences in the mechanisms, evaluated by each method, as well as the difference in the solubility of the molecules, during the reaction. Both assays were performed in a polar media, but, while the $\mathrm{DPPH} \bullet$ scavenging occured at room temperature, in the phosphomolybdenum test, the samples were submitted to a water bath at $90^{\circ} \mathrm{C}$. The high temperature in the second assay could contribute to the solubilization of more apolar compounds.

A similar response profile was observed by Damasceno et al. (2018) for the essential oil of Ocotea bicolor leaves. This species presented low activity in the DPPH assay $\left(\mathrm{IC}_{50}>500 \mu \mathrm{g} / \mathrm{mL}\right)$, but an antioxidant capacity comparable to the ascorbic acid (102.5\%) in the phosphomolybdenum method (Damasceno et al., 2018). In contrast, the essential oil from Ocotea quixos and Ocotea bofo calyces inhibited $52 \%$ and $64.4 \%$ of the DPPH oxidation, respectively (Bruni et al., 2003; Guerrini et al., 2006).

In the $\beta$-carotene bleaching assay, at the end of 120 minutes of reaction, the essential oil was unable to prevent the lipid peroxidation. Also, based on the values calculated for F1 and F2, the sample didn't interfere with the speed of the reaction. F1 indicates the sample's ability to interfere in the formation of peroxide radicals, either by accelerating it or slowing it down, and F2 concerns the second stage of oxidation.

When tested for the antioxidant capacity, using the same mechanism, Ocotea bofo could inhibit $75.8 \%$ of the $\beta$-carotene degradation (Guerrini et al., 2006).

The essential oil tested can be characterized as a complex mixture, composed of substances with various functional groups and polarity. For samples such as this, the varying results are expected, depending on the test employed (Sacchetti et al., 2005) Sesquiterpenes hydrocarbons, the major class found in the essential oil tested, has low antioxidant activity in the TBARS and ABAP assays (Ruberto, Baratta, 2000). This fact might explain the results obtained in the DPPH and $\beta$-carotene bleaching experiments. However, the results from the phosphomolybdenum formation complex indicate that the antioxidant activity should be further explored, using different methodologies.

The preliminary in vitro toxicity test showed a low activity against Artemia salina (Table II), according to the stratification system by Amarante et al. (2011). The toxicity against brine shrimp has already been described for other Ocotea species: O. praetermissa-IC $\mathrm{IC}_{50}: 31.6 \mu \mathrm{g} / \mathrm{mL}$, O. endresiana- $\mathrm{IC}_{50}: 6.9 \mu \mathrm{g} / \mathrm{mL}$ (Agius et al., 2007), O. notate- $\mathrm{IC}_{50}: 2.37 \mu \mathrm{g} / \mathrm{mL}$ (Garrett et al., 2010), O. bicolor- $\mathrm{IC}_{50}: 40.10 \mu \mathrm{g} / \mathrm{mL}$ (Damasceno et al., 2018).

Although the essential oil toxicity against Artemia salina is considered low, it indicates the presence of molecules capable of interacting with biological systems, causing some type of alteration. Thus, toxic results against

TABLE II - Results from the DPPH• scavenging, phosphomolybdenum complex formations, and brine shrimp lethality assays

\begin{tabular}{|c|c|c|c|c|}
\hline \multirow{2}{*}{$\begin{array}{c}\text { DPPH• } \\
\text { scavenging }(\%)\end{array}$} & \multicolumn{3}{|c|}{ Phosphomolybdenum complex } & \multirow{2}{*}{$\begin{array}{c}\text { Brine shrimp lethality } \\
\left(\mathrm{IC}_{50}-\mu \mathrm{g} / \mathrm{mL}\right)\end{array}$} \\
\hline & AAR ascorbic acid (\%) & AAR BHT (\%) & AAR rutin (\%) & \\
\hline $10.22 \pm 0.40$ & $89.17 \pm 5.74$ & $134.10 \pm 8.63$ & $284.62 \pm 18.30$ & $\begin{array}{c}602.81 \\
(424.09-744.06)\end{array}$ \\
\hline
\end{tabular}

Note: (AAR) Antioxidant activity related (to) 
(A)

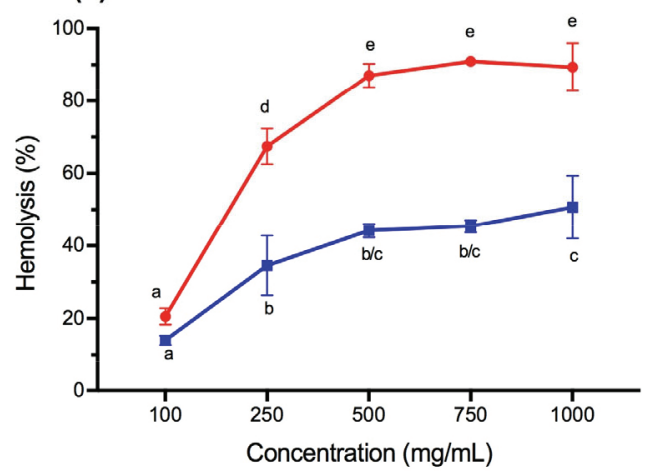

(B)

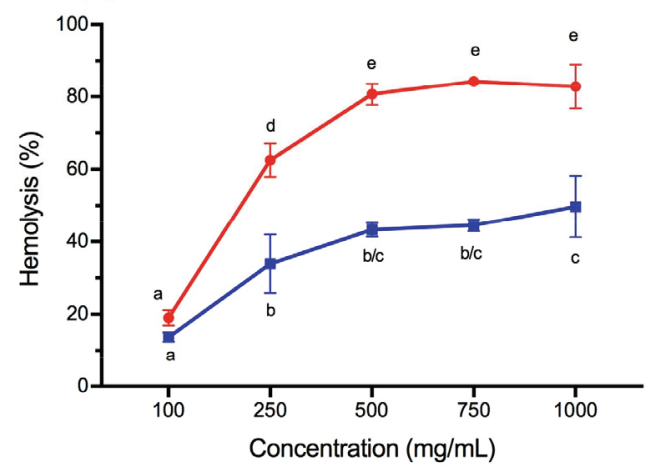

$\rightarrow$ Saponine

$\rightarrow-$ Essential oil

FIGURE 1 - Results obtained in the hemolysis assay when compared to (A) triton $0.1 \%(\mathrm{w} / \mathrm{v})$ and (B) potable water. Note: Results followed by the same letter, in the same graph, belong to the same statistical group.

Artemia salina can be used as a screening process for biologically active samples (Amarante et al., 2011). A study performed using plants from the Asteraceae family showed a possible correlation between the Artemia salina results and anti-Trypanosoma cruzi activity (Zani et al. 1995).

Therefore, the ability to interact with red blood cells membranes, causing hemolysis, is a cytotoxicity indicator (Sharma, Sharma, 2001). Hence, the hemolysis assay results obtained (Figure 1) corroborate with the Artemia salina lethality test. The hemolysis caused by the oil reached a maximum of $50 \%$, probably due to the limitation of its solubility in the solution.

TABLE III - Results from the phytotoxicity in Lactuca sativa var. and Grand Rapids TBR seeds

\begin{tabular}{lcc}
\hline Sample & $\begin{array}{c}\text { Concentration } \\
(\mathbf{\% ~ m / v )}\end{array}$ & \begin{tabular}{c} 
Hypocotyl $(\mathbf{m m})$ \\
\cline { 3 - 3 }
\end{tabular} \\
\hline Control water & - & $29.87 \pm 7.43^{\mathrm{b}}$ \\
Control Tween $80^{\circledR}$ & - & $29.90 \pm 9.84^{\mathrm{b}}$ \\
Essential oil & 0.001 & $32.15 \pm 9.73^{\mathrm{b}}$ \\
& 0.01 & $30.35 \pm 10.32^{\mathrm{b}}$ \\
& 0.1 & $29.75 \pm 2.86^{\mathrm{b}}$ \\
& 1 & $16.00 \pm 6.21^{\mathrm{a}}$ \\
\hline
\end{tabular}

Note: Results followed by the same letter belong to the same statistical group.

The phytotoxicity results showed no interference with the germination of Lactuca sativa seeds and the growth of its radicle. The hypocotyl growth was affected by only the tested $1 \%(\mathrm{w} / \mathrm{v})$ concentration (Table III). The phytotoxicity of Ocotea quixos was also evaluated by Rolli et al. (2014), and its essential oils delayed the germination of Solanum lycopersicum seeds and inhibited its root growth.

\section{ACKNOWLEDGEMENTS}

The authors are thankful to CAPES and CNPQ, for the financial support.

\section{CONFLICT OF INTEREST}

The authors declare no conflict of interest.

\section{REFERENCES}

Adams RP. Identification of essential oil components by gas chromatography/mass spectroscopy. Illinois: Allured Pub Corp; 1995.

Agius BR, Setzer MC, Stokes SL, Walker TM, Haber WA, Setzer WN. Composition and bioactivity of essential oils of Lauraceae from Monteverde, Costa Rica. Int J Essent Oil Ther. 2007;1(1):167-71.

Amarante CB, Müller AH, Póvoa MM, Dolabela MF. Estudo fitoquímico biomonitorado pelos ensaios de toxicidade frente à Artemia salina e atividade antiplasmódica do caule de aninda (Montrichardia linifera). Acta Amaz. 2011;41(3):431-4.

Banerjee A, Kunwar A, Mishra B, Priyadarsini KI. Concentration dependent antioxidant/pro-oxidant activity of curcumin studies from AAPH induced hemolysis of RBCs. Chem-Biol Interact. 2008;174(2):134-9.

Bruni R, Medici A, Andreotti E, Fantin C, Muzzoli M, Dehesa $\mathrm{M}$, et al. Chemical composition and biological activities of Ishpingo essential oil, a traditional Ecuadorian spice from Ocotea quixos (Lam.) Kosterm (Lauraceae) flower calices. Food Chem. 2004;85(3):415-21. 
Cansian RL, Mossi AJ, Paroul N, Toniazzo G, Zboralski F, Prichoa FC, et al. Atividade antioxidante e antimicrobiana de extratos de canela-sassafrás (Ocotea odorifera (Vell.) Rowher). Perspectiva. 2010;34(127):123-33.

Chaverri C, Cicció JF. Essential oil of trees of the genus Ocotea (Lauraceae) in Costa Rica. I. Ocotea Brenesii. Rev Biol Trop. 2005;53(3-4):431-6.

Damasceno CSB, Oliveria LF, Szabo EM, Souza AM, Dias JFG, Miguel MDM, et al. Chemical composition, antioxidant and biological activity of Ocotea bicolor Vattimo-Gil (Lauraceae) essential oil. Braz J Pharm Sci. 2018;53(4):1-8.

Duarte-Almeida JM, Santos RJ, Genovese MI, Lajolo FM. Avaliação da atividade antioxidante utilizando sistema $\beta$-caroteno/ácido linoleico e método de sequestro de radicais DPPH•. Ciênc Tecnol Aliment. 2006;26(2):446-52.

Duke JA, Vásquez R. Amazonian ethnobotanical dictionary. Bora Raton: CRC Press; 1994.

Farmacopéia Brasileira. 5 ed. Atheneu: São Paulo; 2010.

Garrett R, Cruz RAS, Rocha L, Santos MG, da Silva AJR. Chemical composition and toxicity of Ocotea notate (Nees) Mez essential oil. J Essent Oil Bear Pl. 2010;13(1):455-9.

Guerrini A, Sacchetti G, Muzzoli M, Rueda GB, Medici A, Besco E, et al. Composition of the volatile fraction of Ocotea bofo Kunth (Lauraceae) calyces by GC-MS and NMR fingerprinting and its antimicrobial and antioxidant activity. J Agric Food Chem. 2006;54(20):7778-88.

Marques CA. Importância econômica da família Lauraceae Lindl. Floram. 2001;8(1):196-206.

Martins A, Hajdú Z, Vasas A, Csupor-Löffler B, Molnár J, Hohmann J. Spathulenol inhibit the human ABCB1 efflux pump. Planta Med. 2010;76(12):608.

Mensor LL, Menezes FS, Leitão GG, Reis AS, Santos TCdos, Coube CS, et al. Screening of Brazilian plant extracts for antioxidant activity by the use of DPPH free radical method. Phytor Res. 2001;15(2):127-30.

Meyer BN, Ferrigni NR, Outnam JE, Jacobsen LB, Nichols DE, McLaughlin JL. Brine shrimp: A convenient general bioassay for active plant constituents. Planta Med. 1982;45(5):31-4.
NIST-US National Institute of Standards and Technology. NIST/ EPA/NIH Mass Spectral Database, PC version 10. Gaithersburg: US Department of Commerce; 1998.

Prieto P, Pineda M, Aguilar M. Spectrophotometric quantitation of antioxidant capacity through the formation of a phosphomolybdenum complex: Specific application to the determination of vitamin E. Anal Biochem. 1999;269(2):337-41.

Rolli E, Marieschi M, Maietti S, Sacchetti G, Bruni R. Comparative phytotoxicity of 25 essential oils on pre- and post-emergence development of Solanum lycopersicum L.: A multivariate approach. Ind Crops Prod. 2014;60(1):280-90.

Ruberto G, Baratta MT. Antioxidant activity of selected essential oil components in two lipid model systems. Food Chem. 2000;69(2):167-74.

Rufino MdoSM, Alves RE, Brito ES, Filho JM, Moreira AVB. Metodologia científica: Determinação da atividade antioxidante total em frutas no sistema $\beta$-caroteno/ácido linoleico. Comun Técn Online. 2006;126(1):1-4.

Ruschel AR, Nodari ES, Guerra MP, Nodari RO. Evolução do uso e valorização das espécies madeiráveis da floresta estacional decidual do Alto-Uruguai, SC. Cien Flor. 2003;13(1):153-66.

Sacchetti G, Miaetti S, Muzzoli M, Scaglianti M, Manfredini $\mathrm{S}$, Radice M, et al. Comparative evaluation of 11 essential oils of different origin as functional antioxidants, antiradicals and antimicrobials in food. Food Chem. 2005;91(4):621-32.

Santos LBdos, Souza JK, Papassoni B, Borges DGL, Junior GAD, Souza JMEde, et al. Efficacy of extracts from plants of the Brazilian Pantanal against Rhipicephalus (Boophilus) micropilus. Rev Bras Parasitol Vet. 2013;22(4):532-8.

Salleh WMNHW, Ahmad F. Phytochemistry and biological activities of the genus Ocotea (Lauraceae): A review on recent research results (2000-2016). J Appl Pharm Sci. 2017;7(5):20418.

Sharma P, Sharma JD. In vitro hemolysis of human erythrocytesby plant extracts with antiplasmodial activity. J Ethnopharmacol. 2001;74(3):239-243.

Silva ER, Overbeck GE, Soares GLG. Phytotoxicity of volatiles from fresh and dry leaves of two Asteraceae shrubs: Evaluation of seasonal effects. S Afr J Bot. 2014;93:14-8. 
Takaku S, Haber WA, Setzer WN. Leaf essential oil composition of 10 species of Ocotea (Lauraceae) from Monteverde, Costa Rica. Biochem Syst Ecol. 2007;35(1):525-32.

Wang XS, Yang W, Tao SJ, Li K, Li M, Dong JH, et al. The effect of $\delta$-elemene on hela cell lines by apoptosis induction. Yakugaku Zasshi. 2006;126(10):979-90.

Weber LD, Scur MC, Souza JGdeLde, Toledo AG, Pinto, FGdaS. Antimicrobial activity and phytochemical prospection of vegetal extracts of Ootea silvestris Vattimo-Gil and Ocotea diospyrifolia (Meisn.) against serotypes of Salmonella of poultry origin. Rev Bras Saúde Prod Anim. 2018;19(1):116-24.

Xie CY, Yang W, Li M, Ying J, Tao SJ, Li K, et al. Cell apoptosis induced by delta-elemene in colorectal adenocarcinoma cells via a mitochondrial-mediated pathway. Yakugaku Zasshi. 2009;129(11):1403-13.
Zani CL, Chaves PPG, Queiroz R, Oliveira ABde, Cardoso JE, Anjos AMG, et al. Brine shrimp lethality assay as a prescreening system for anti-Trypanosoma cruzi activity. Phytomedicine. 1995;2(1):47-50.

Zhang F, Xu L, Qu X, Zhao M, Jin B, Kang J, et al. Synergistic antitumor effect of $\beta$-elemene and etoposide is mediated via induction of cell apoptosis and cell cycle arrest in non-small cell lung carcinoma cells. Mol Med Rep. 2011;4(6):1189-93.

Zhang X, Li Y, Zhang Y, Song J, Wang Q, Zheng L, et al. Betaelemene blocks epithelial-mesenchymal transition in human breast cancer cell line MCF-7 through Smad3-mediated downregulation of nuclear transcription. PLoS One. 2013;8(3):1-8.

Received for publication on $03^{\text {th }}$ July 2018 Accepted for publication on $23^{\text {rd }}$ September 2018 